\title{
Architecture in Southern African informal settlements: A contextually appropriate intervention
}

\begin{abstract}
Architectural professionals can contribute to efforts at achieving sustainable urbanism. However, the realm of professional discourse is extremely limited. Grounded architectural practice (GAP) is developed as a conceptual framework to explore an emergent form of contextually appropriate architectural practice in the context of a resident-driven in situ informal settlement upgrading project. The exploration takes the form of a descriptive narrative. Each challenge that arose during the descriptive narrative was mapped according to Engeström's activity system model, an analytical tool emanating from cultural-historical activity theory (CHAT). By participating in live projects in informal settlements and analysing these projects by means of CHAT, the authors explored the highly improvising and generative everyday practices of the urban majority. Architectural practice in such a context requires a multi-disciplinary approach which extends beyond conventional professional boundaries, and attention must be paid to building the capacity of all participants to function in such uncharted territory.
\end{abstract}

Keywords: sustainable urbanism, informal settlements, in situ upgradings, architectural practices, live projects, activity theory

\section{Introduction}

As is the case in the collapse of communism (Mariotti \& KoZelf, 2016) the collapse of apartheid which occurred more or less at the same time in history had direct consequences for the structure and form of these cities. According to Osman, racially segregated apartheid planning perpetuates today because there has never been a major rethink about how cities and housing are planned. This lack of imagination is further exacerbated by unequal funding patterns that entrench the status quo. Standalone, monofunctional housing models result in residential environments that remain poorly located, poorly serviced and highly segregated (2015).

During the first decade of democracy (1994-2003) the South African national housing policy was primarily geared towards meeting low-cost housing delivery targets. During this time an estimated 1.4 million houses were built (Tissington 2010), whilst millions are still in search for alternative housing opportunities, such as squatting and renting (Gunter, 2014). With the introduction of the "Breaking New Ground: A Comprehensive Plan for the Development of Sustainable Human Settlements" policy in 2004 informal settlement eradication through phased in-situ upgrading featured as one of the key aspects of spatial restructuring (Aigbavboa \& Thwala, 2010; Huchzermeyer, 2011, 2010; Cirolia, Smit \& Duminy 2015; Tissington, 2010; Royston, 2009). However, since then, possibility of implementing the BNG's Upgrading of Informal Settlements Programme seems to have dissipated (Cooke, 2014; Fieuw, 2014). In reality the method through which in situ upgrading is implemented is nothing less than de facto forced removals. Such relocation results in sharp increases in transportation costs, disrupting fragile livelihood networks and income generating activities. 
When existing informal settlements are eventually redeveloped, implementation takes place over extended periods of time and at much lower densities (Chenwi, 2008; Huchzermeyer, 2010, 2011; Ziblim, 2013) and standard of housing units are questionable (Aigbavboa \& Thwala, 2014). Not surprisingly, informal settlement residents view relocation with deep scepticism, as temporary relocation areas (TRAs) often become de facto permanent settlements (Jordhus-Lier, 2015).

Urban upgrading projects - whether formal or informal - are complex and multidisciplinary. In interventions such as these, the architectural profession as member of the built environment profession, along with planning and engineering, has an important role to play (Osman, 2015). Aravena notes the challenge which the complexity of dealing with and planning for informality poses to professionals who engage in in situ upgrading. He states that "battles need to be won and frontiers need to be expanded" (2015) in order to improve the quality of the built environment and thus the urban majority's quality of life. The battles he referred to require collaborative action and shared knowledge. Datta (2008: 250) claims that it is important to examine architecture within the developmental context of the global South - particularly in circumstances when it is being transformed through the politicized practices of its users - in order to fully understand its role in civil society.

As is the case with urban planners, dealing with informality means "confronting how the apparatus of planning produces the unplanned and unplannable" (Roy, 2005: 156). Evermore architectural professionals engage with grassroots level, resident-driven projects (Miles, 2013). However, the dearth of professionals with the capacity to support such projects poses a substantial challenge (Ziblim, 2013). Such engagement generally occurs in collaboration with or as a member of a locally-based NGO (see for example the role of Development Action Group (DAG) in the case study of Freedom Park - Mah \& Rivers 2013), contributing to the sustainability of the project by tapping into pre-existing relationships with informal settlement residents. Brown-Luthango et al. (2016) state that interventions in the built form through the provision of physical infrastructure have been proposed as a strategy to improve economic, social and health outcomes for informal settlement dwellers and are also suggested as tools to address violence and insecurity, which have reached unprecedented levels in many cities of the South.

The paper proposes that in situ upgrading projects facilitated by NGOs provide the opportunity to explore an emergent form of contextually appropriate and sustainable architectural practice. The paper begins by contextualising in situ upgrading as a transition towards sustainable urbanism. The inability of the architectural profession to deal with informality and to support in situ upgrading is discussed next with grounded architectural practice (GAP) posited as an emerging mode of practice. In the remaining sections of the paper insight is gained into a more informed and grounded architectural practice by drawing on empirical research conducted in the informal settlement of Lotus Park in Cape Town.

\section{Architectural professionals: A history of entrenched exclusivity}

Urban informality has been on the research agenda for decades (Roy, 2005; Varley, 2013). In the discourse of informality there has been a resurgence of interest from architecture. Varley (2013: 4) describes this interest "as the product of a renewed social and environmental activism". Town planners are the urban practitioners mostly involved in informality, but according to Roy (2005) this relationship is complicated. Whilst on the one side of the coin 
informal spaces are perceived to be unplannable, on the other side of the coin a range of attempts have been made to improve and integrate such spaces. She further states that informality "must be understood not as the object of state regulation but rather as produced by the state itself" (2005: 149) and furthermore suggests that "to deal with informality therefore partly means confronting how the apparatus of planning produces the unplanned and unplannable" (2005: 156). After all, informality can only occur where governments tend to turn a blind eye to such developments (Ley, 2012). According to Watson (2014: 102) planning theory in global south regions is poorly developed and planning practitioners have very little of relevance to draw on for inspiration in dealing with the complex problems of southern cities. According to her the strategies of poorer urban dwellers as they manoeuvre to gain access to well-located and affordable land and living environments, usually through informal and sometimes violent means - planning theory has had relatively little to offer to counter Euro-American interpretations of urban problems or alternatives to put in their place (Watson, 2014: 102).

As people with specialised abstract knowledge, and trained within strategic fields of responsibility, architectural professionals occupy a central role in society (Sverrisdóttir, 2014). Just as Roy (2005: 155) proclaims that engagement with informality is in many ways quite difficult for planners because informal spaces "seem to be the exception to planning, lying outside its realm of control" so too is it true for architectural professionals. To engage with the architecture of informality is to undertake the task of informalising architectural practice and a rethinking of professional ideology, architectural theory and education (Dovey, 2013: 87). The realm of professional discourse is therefore extremely limited and lacks the "ability to reach an appropriate collective discussion field of the various stakeholders" (Sverrisdóttir, 2014: 106). Osman (2015) agrees, stating that the profession has the potential to offer spatial, technical and social expertise, yet remains relatively disengaged, isolated and elitist. As early as two decades ago, Mayet appealed to the profession to "change course from a history of entrenched exclusivity" (1995: 49) and addresses the needs of our changing society, not only to regain its relevance but to ensure its survival. To support informal settlement residents in their stubborn appropriation of the city is viewed by some as an ethical obligation (Pieterse, 2008). Reflecting on this, Combrinck posits that the profession's dilemma is a result of "the (in)ability to engage meaningfully in an [informal] context that fundamentally challenges the construct of professional architectural service" (2015:3-4).

Despite calls from the profession itself for participation and ongoing engagement with informal settlement communities, alternative approaches are not yet the norm. Neither have the architectural professionals strongly influenced how the discipline is taught and practised nor how professional institutes and councils operate (Osman, 2015). The profession still focuses on wealthy clients and on the architect as 'creative individual'. When working in complex, low-income, politically polarised contexts, approaches privileging the role of the architectural professional as designer - in direct opposition to a user centred approach - is highly problematic and irrelevant (Osman, 2015). Ideally architectural professionals have to engage with informal settlement residents in a participatory design process as co-designers, rather than clients or beneficiaries (Newton, 2013; Gianotti \& Mathiesen, 2014). Informal urbanism is a global concern which challenges formal systems of governance, economy and social justice. However, the architectural profession remains marginal to this discourse, with "recognised contributions seen as intermittent, exceptional and once off" (Combrinck, 2015: iv). 


\section{Grounded architectural practice (GAP)}

Davis (2006) homogenises informal settlement residents' attempts at leading an urban life and describes them as an undifferentiated and apolitical global mass of urban squatters. Similarly, Jack (cited in Pieterse, 2008) describes the 'urban poor' as a 'blank figure', without making reference to the conditions they face every day. Such impoverished thinking locates informal settlements in a theoretical context that is blind to the agency, skill, endurance and effort that constitute the livelihood strategies of the urban majority (ibid.). Yet, Aravena (2015) states that we want to learn from architectures that, despite (or perhaps because of) a scarcity of means, intensify what is available instead of complaining about what is missing. We want to understand what design tools are needed to subvert the forces that privilege individual gain over collective benefit.

This statement is supported by scholars who recognise the potential, and persistence, of grassroots practices. Bayat refers to "combined and continuous processes of informalisation, integration and re-informalisation" (1997: 61), and Murray characterises informal settlements as "incubators for inventive survival strategies where inhabitants have begun to ... develop their own specific forms of collaboration and cooperation" (2008: 33). The city can be described as a fundamentally emergent and therefore open-ended reality (Byrne, 2001). This perspective facilitates the undoing of the artificial boundary that separates the formal from the informal (Schoon \& Altrock, 2014). GAP can be interpreted as occupying the space where this boundary has been removed (Figure 1). GAP enables the architectural profession to achieve meaningful transformation by embedding practice in the continually changing, complex and dynamic systems of informal urbanism, where the highly improvising and generative everyday practices of the urban majority can be explored (Pieterse, 2008; Kakembo \& Van Niekerk, 2014). In this context, the technical and theoretical skills associated with architectural practice - and the tendency to 'default into design' when confronted with complex issues (Combrinck, 2015) - yield a deeper appreciation and openness towards different ways of seeing and responding to problems. To facilitate this, Cooke (2014) encourages architectural professionals to engage in local level partnerships and practices, such as enumerations and reblocking (Enumerations are resident-driven censuses to generate socio-economic and demographic settlement profiles, including tenure status, services levels and development aspirations. Reblocking is the spatial reconfiguration of dwellings to allow for vehicular access and installation of service infrastructure). He further describes in situ upgrading as a collaborative project where leadership continually shifts between different disciplines and stakeholders: in essence, a multi-disciplinary approach that extends beyond conventional professional boundaries. Transforming spaces through GAP can lead to a transformation of place identity through architectural awards for upgrading projects (changing negative perceptions of informal areas to positive perceptions; Dovey \& King, 2011). 


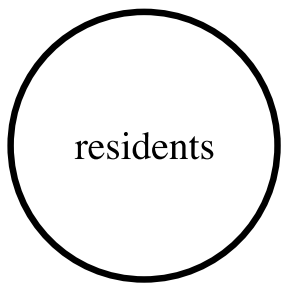

informal
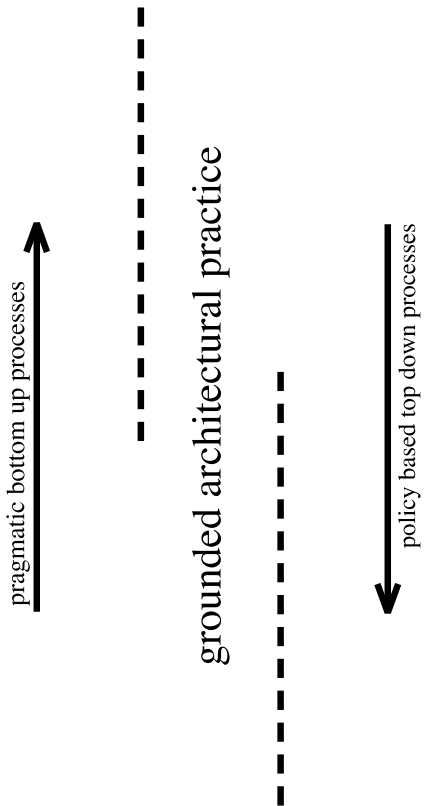

formal

Figure 1: Grounded architectural practice (GAP) in the context of undoing of the artificial boundary between formal and informal (illustration: Rudolf Perold).

The conceptual framework of GAP employed in the paper derives from two perspectives. Firstly, Goonewardena: "being grounded in reality ... overcoming existing relations separations - between abstract processes and concrete life" (2008: 118). Secondly, morally engaged work that is constructive through critiquing existing ideas and reconstructing alternatives ... [and involving] processes of conceptual deconstruction and reconstruction [which] build from grounded engagement with empirical realities and political imperatives (Oldfield et al., 2004: 295).

The remainder of the paper will explore GAP as field of mediation between the pragmatic bottom-up strategies of informal settlement residents and their supporting NGOs, and the topdown, policy-driven strategies of government. Combrinck's (2015) critique that beyond reporting on individual cases, very little knowledge is generated about contextually appropriate and sustainable modes of architectural practice. The mode of architectural practice which this paper sets out to explore takes place in a contested setting.

\section{Research method}

The research method employed explores GAP by utilising a number of phenomenological methods (Kleining \& Witt, 2000; Seamon, 2000; Hiles, 2001; Yaneva, 2011). This approach also draws on action research, a subjective, collaborative, reflective and experiential method (Abdel-Fattah, 2015) which turns all participants - both residents and architectural professionals - into researchers whose capacities are enhanced in the process. The exploration of GAP is facilitated by engaging in an in situ informal settlement upgrading project in Cape Town in order to gather empirical data for qualitative analysis. The project was embedded within an existing long-term NGO intervention, where an effective working relationship has been established with the residents of Lotus Park. 
The exploration takes the form of a descriptive narrative, which will be drawn on in the subsequent analysis. Each challenge which arose during the descriptive narrative was mapped according to Engeström's activity system model (Figure 2), an analytical tool emanating from cultural-historical activity theory (CHAT). CHAT comprises five principles (Engeström, 1999a): activity system as unit of analysis; multi-voicedness and different perspectives; historicity; contradictions as source of change; and, expansive transformation. The unit of analysis in CHAT is a historically evolving collective activity system, such as architectural practice, observed in its network relations to other activity systems (Engeström, 2000). CHAT is concerned with "doing in order to transform something" and considers the contextualised activity of the system as a whole as the "minimum meaningful context" for understanding human actions (Engeström, 1993: 67).

$$
\begin{array}{|l|l|}
\hline \text { - }- \text { object } & \mathrm{r}-\text { rules } \\
\mathrm{s}-\text { subject } & \mathrm{d}-\text { division of } \\
\mathrm{t}-\text { tools } & \text { labour } \\
\mathrm{c}-\text { community }
\end{array}
$$

local government

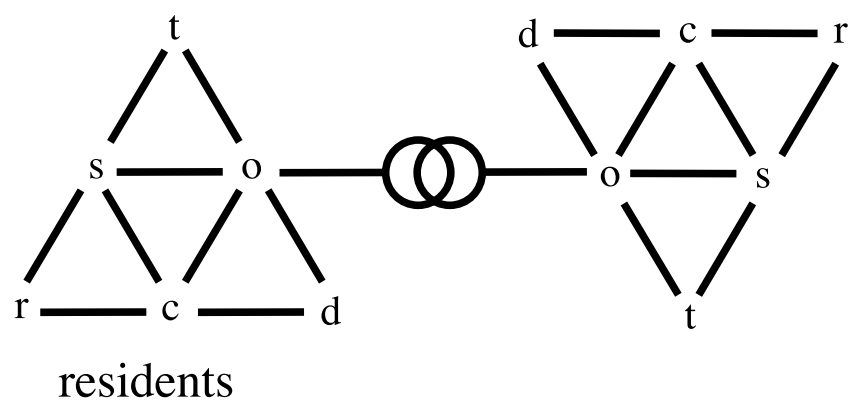

Figure 2: Engeström's model of two activity systems with a potentially shared object (source: Engeström, 2009: $305)$.

The participants are placed in the position of subject, and their agency is the point of view employed in the analysis. The aspect of agency makes places and spaces part of the "practice of interrelation' which are continuously shifting and multiplying. If architecture is the site of active and embodied spatial practice, then like space, architecture too is tied up with the 'entanglements of power' that shape and are shaped by productive acts of agency (Datta, 2008: 233).

The 'acted upon' - in the case of this paper, the in situ upgrading - is placed in the position of object, and defined as problem spaces at which activity is directed and which is moulded or transformed into outcomes with the help of physical and symbolic, external and internal tools (Engeström, 1987: 79). Tools, together with community, rules and division of labour, mediate the relationship between subject and object in order to achieve an outcome. When challenges arise during the activity, they are conceptualised as contradictions either within or between the nodes of the activity system model (CRADLE, 2016). Contradictions can be overcome by means of knotworking, described as the construction of constantly changing combinations of people and artefacts over lengthy trajectories of time and widely distributed in space, and characterised by a pulsating movement of tying, untying and retying otherwise separate threads of activity (Engeström, 1999a: 345-346). The unstable knot itself is the focus of analysis. By analysing these contradiction and how they are resolved through knotworking, 
insight can be gained into the capacity building which occurs when architectural professionals engage in contextually appropriate and sustainable modes of practice. The analytical framework (Figure 3) summarises how CHAT was used in the case study analysis.

\section{Written description of contradiction and how it was overcome}

Contradictions are historically accumulating structural tensions within and between activity systems, consequently causing a change (breakdown or development) in people's activities or in themselves. Contradictions often manifest themselves as problems, ruptures, breakdowns, clashes, or as disturbances that interrupt the flow of work (Ekundayo, Wang \& Andrade 2012: 2).

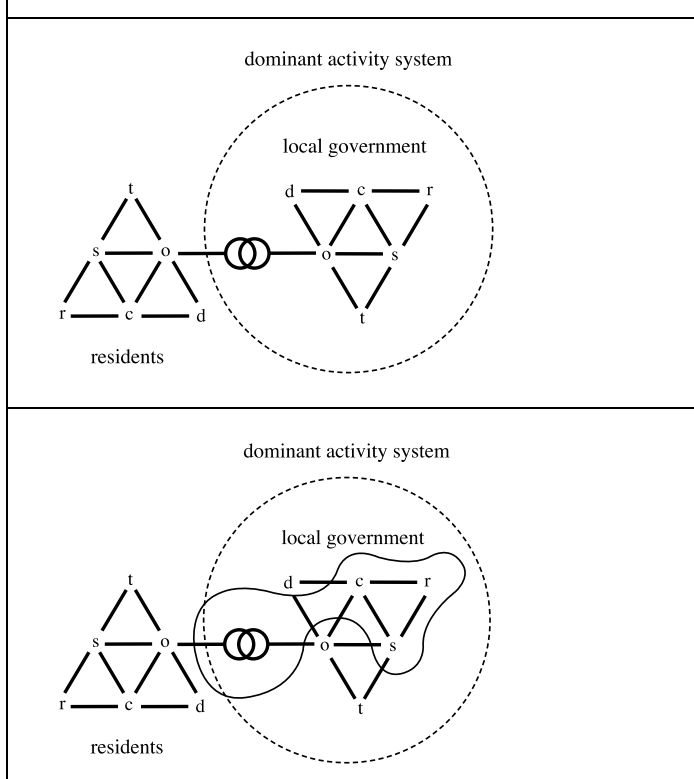

\section{Dominant activity system}

The dotted circle indicates in which activity system (residents, local government, or a both) the locus of activity (GAP) is located (i.e. which system is more prominent at the moment when the contradiction arises).

\section{Knotworking}

The curvilinear knot device shows where the unstable knot between two activity networks is located (i.e. which nodes of the activity systems are most prominent in resolving the contradiction).

\section{Twin principles of expansive learning}

Expansive learning is a historically new type of learning that emerges as practitioners struggle through developmental transformations in their activity systems and move across collective zones of proximal development (Engeström 1999b: 7). Accordingly, expansive learning occurs in the construction and resolution of successive contradictions in the activity system (Engeström 1999b: 12), and is informed by two related principles:

Double stimulation:

This entails the introduction and collaborative application of new tools (potentially useful mediating artefacts) with the capacity to reveal potential capabilities and emerging new psychological formations. Subjects are placed in a situation in which a problem is identified and they are also provided with tools (or the means to construct tools) with which to solve the problem (Daniels 2011: 361). Double stimulation leads to a concept of formative interventions, which aim to generate intermediate concepts and solutions to be used in other settings in the design of locally appropriate solutions (Engeström 2009: 321).

Ascending from the abstract to the concrete:

This dialectical method is a central tool for mastering cycles of expansive learning. Dialectical logic starts from the assumption that development is driven through contradictions, and entails the analysis of the development trajectory of the object. Starting with an initial undeveloped form (germ cell) is critically important for understanding how the 
object has come to be what it is, and what contradictions can be expected to drive its further development (Kaptelinin, 2013).

Figure 3: Analytical framework based on Engeström's model of two activity systems and the principles of CHAT (source: Engeström, 2009: 305).

\section{Case description}

During the 1980s Lotus Park, an area located in the impoverished black township of Gugulethu in Cape Town (Figure 4), was a forested area between the Metrorail Central Line and the Lotus River Canal, with footpaths from Nyanga Station to Gugulethu which were subject to frequent robberies, especially during early mornings and late evenings (VPUU, 2011). By the mid-1990s the area had gradually become deforested by residents collecting firewood and the resultant open field soon became a dumping ground for household refuse. To relocate flooding victims living in Waterfront, on the opposite side of the canal, a local steering committee was elected to manage the allocation of sites, and during late 2003 the first residents from Waterfront moved into Lotus Park. They were followed by flooding victims from Gxagxa the next year, as well as backyard dwellers from the Khikhi Hostel. Conflicts subsequently arose as now three groups of people were competing for the same area. These conflicts were exacerbated by corruption, where committee members tasked to allocate sites instead sold them in a disorganised manner (VPUU, 2011). 


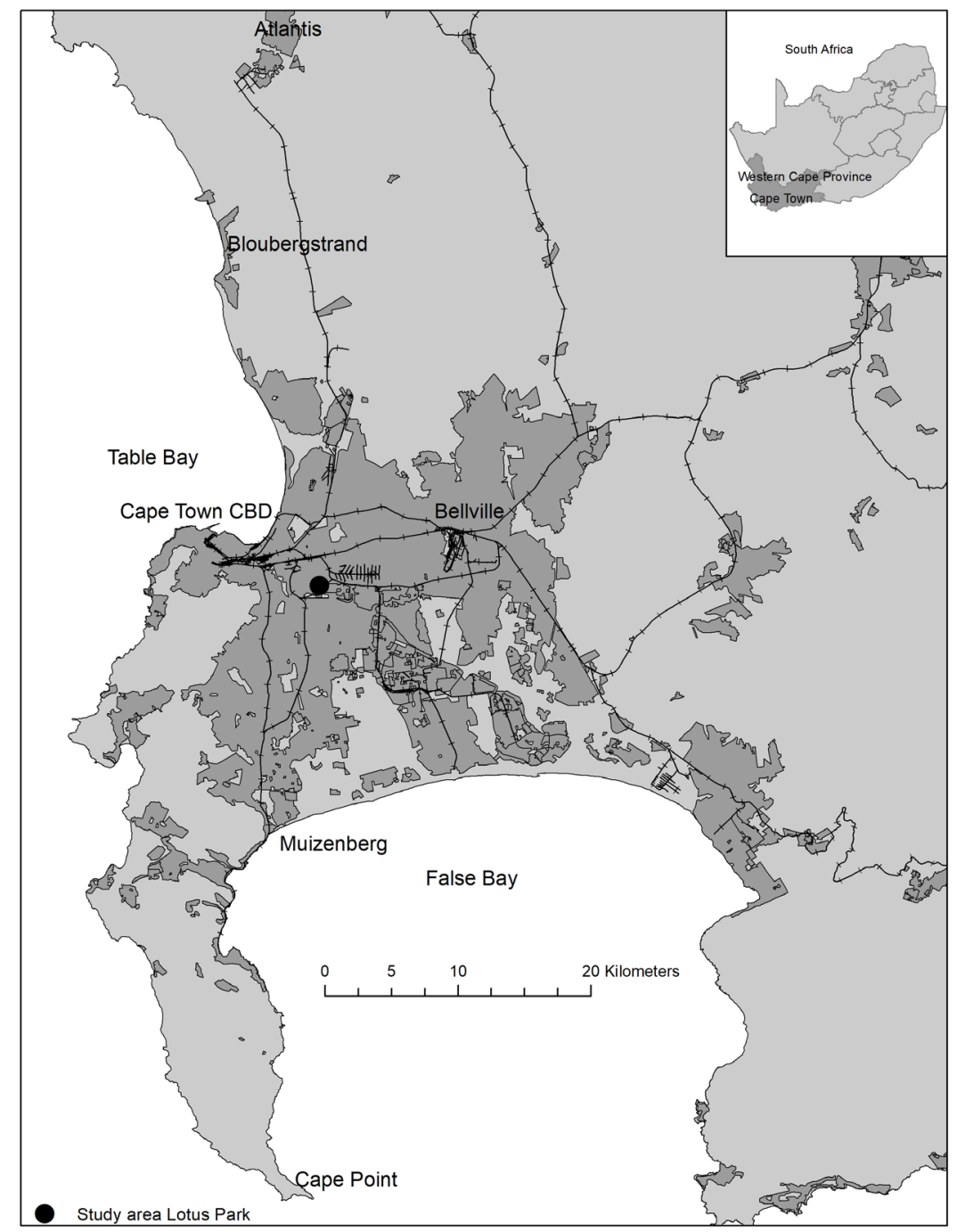

Figure 4: Case study of Lotus Park location in Cape Town Metropolitan Region (illustration: Rudolf Perold).

During 2009, despite continued conflict (now the result of division along party political lines) the residents embarked on service delivery protests, with the bucket system sanitation and the dangerous environment as key issues. In response to the protests, the City of Cape Town (CoCT) requested VPUU to adapt their methodology within an "Informal Settlement Transformation Programme", using an in situ developmental approach. Lotus Park was one of three pilot sites identified (VPUU, 2014a). In 2010, VPUU (and their implementation agent SUN Development) were introduced to the local steering committee as an agency that would facilitate the infrastructure development of the settlement. VPUU were to act as an intermediary between the Lotus Park residents, the CoCT, Western Cape Government and other stakeholders. A baseline survey (VPUU, 2011) was conducted which informed the Community Action Plan (CAP) - a local area development plan identifying projects and interventions by all stakeholders. The CAP consists of a combination of spatial layers and work streams and guided the development of the spatial reconfiguration plan which included a subdivision plan to enable incremental tenure and a precinct plan for a neighbourhood centre (VPUU, 2014b), the focus in the paper.

The area indicated for the Lotus Park Neighbourhood Centre (NHC) belongs to the CoCT, and was used as a dumping ground for household refuse. As Lotus Park is not recognised as a formal settlement, the building had to be temporary in nature in order to be approved by the 
Building Control Department, which resulted in some initial resistance from the Lotus Park residents. The NHC was designed by VPUU's in-house architectural professionals and the project brief was developed collaboratively with a committee of residents. Rough models were used throughout the design process. The building process commenced in July 2013, and although planned for six to nine months, it took a year. Employing local residents as labourers involved a mentoring process by the contractor's skilled craftspeople, resulting in the sandbag wall construction of the hall having had to be rebuilt three times. Problems relating to the use of non-standard size shipping containers for the rest of the NHC also involved a redesign of certain parts of the building while construction was underway.

The project reached practical completion during July 2014, but the architectural professionals remained involved in the process of the local committee and when residents started using the building prior to the official opening in November. This extended involvement was crucial in addressing problems resulting from the use of a non-conventional greywater recycling system, in lieu of a municipal sewer connection. The NHC functions as a safety catalyst and provides desperately needed community facilities, including offices for local organisations, meeting rooms and a hall, early childhood development (ECD) facilities and an emthonjeni a multifunctional space with a selection of utilities (e.g. water points), places for gathering, playing, washing and conducting business (Ewing, 2015). An existing kickabout space adjacent to the NHC was upgraded into a hard court soon after completion of the NHC and a walkway from the main road (NY3) to the NHC was completed in 2015.

\section{Case analysis and findings}

The three contradictions of the Lotus Park NHC project that will be discussed are represented in Figure 5.

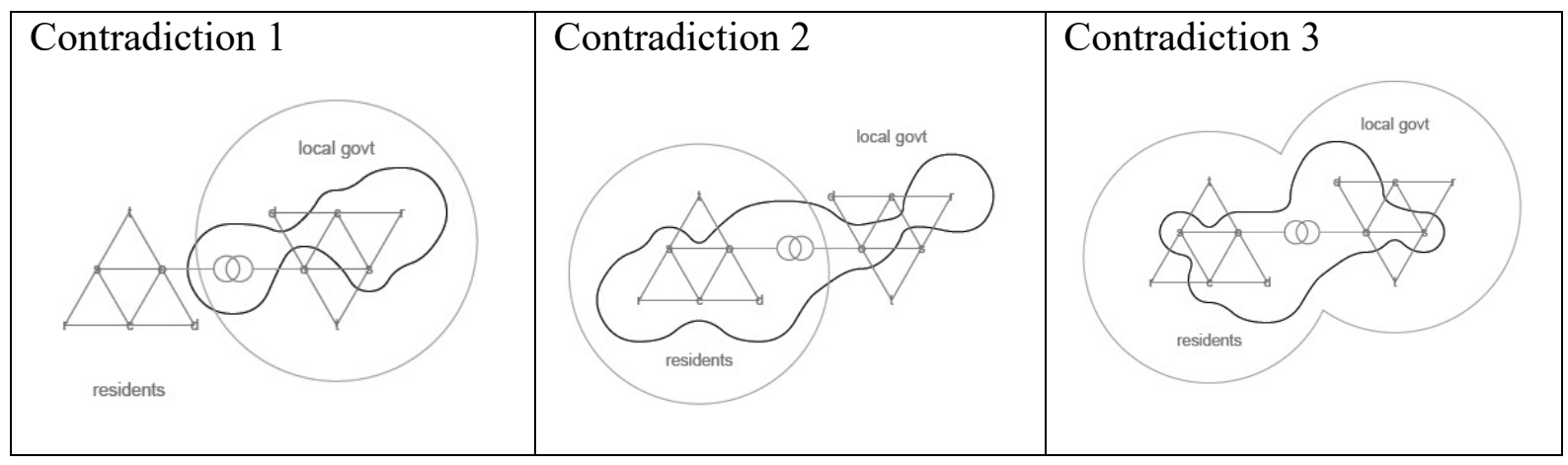

Figure 5: Three contradictions of the Lotus Park NHC project are mapped onto the analytical framework (illustration: Rudolf Perold).

\subsection{Contradiction 1}

As Lotus Park is an informal settlement located on land zoned for infrastructure use, approval for a permanent community structure is not provided for in the statutory framework of the local government (the dominant activity system). In the context of the activity theory, the activity system nodes concerned for the first contradiction are the subject (VPUU architectural professionals), the object (construction of NHC - approval of design), the rules (no permanent structure allowed on land due to current zoning) and the community (COCT official who allowed for approval of temporary building subject to yearly review). Thus there 
is a contradiction between the rules and the object: the rules do not allow for a permanent building, but the object is to design and construct a NHC. This contradiction is overcome by a street-level bureaucrat - a member of the community, in this case a CoCT's Planning and Building Development Department staff member - which allowed a temporary building (subject to yearly review) to be approved, thereby making use of a different rule than is the norm. In the street-level bureaucracy seminal work of Lipsky (1969: 2) his theory intends to explain the role played by street-level bureaucrats in the policy implementation and service delivery, their interaction with the public during public service delivery, exercise of discretion in decision making and the impact they make on how they deliver the said. According to him, despite the bureaucratic and hierarchical structures within which, in this case the community (bureaucrat) operates, such employee does however possess a degree of independence in the execution of their duties. Having been in a position of understanding the context of the case study holistically, the bureaucrat weighed up different concerns regarding the nature of the building. She (CoCT's Planning and Building Development Department staff member) argued that a NHC would add value to the informal settlement. Due to zoning not permitting a permanent public building such as the NHC to be developed on this site she ruled that approval for a temporary building should be applied for. In the context of Lipsky (1969) it is evident that the need for the centre overruled the importance of strictly adhering to the regulations. Bureaucratic independence should therefore not be reduced to decisionmaking within the confines of their given role within an agency, as their attitude and approach to executing policy are just as important in how an agency's clientele views the agency and their government's responsiveness to their particular needs (Holland, 2017: 123).

This independence is discretion in the decision-making process of a street-level bureaucrat. Discretion is defined as "perceived freedom of street-level bureaucrats in making choices concerning the sort, quantity and quality of sanction and reward when implementing" public policy and regulations (Tummers \& Bekkers, 2014: 529). As a consequence of independence and discretion the street-level bureaucrats' decision-making did not only have a significant direct impact on VPUU's intervention in enabling the NHC to be constructed prior to rezoning, but also directly on future users. The subject's experience with the local government in this case can thus be viewed as fair (Lipsky, 1969).

In the context of expansive learning the two core principles are double simulation (problem and tools) and ascending from the abstract to the concrete (germ cell) (Engeström, 2009). In terms of double stimulation, the problem was identified as the inability to obtain approval for a permanent building, whereas alternative rules (temporary building) to obtain approval for design, with support by CoCT official were utilised as tools. Insofar as ascending from the abstract to the concrete is concerned, the germ cell is in fact that not all buildings need to be permanent (perhaps a lesson derived from informality).

\subsection{Contradiction 2}

As the building had to be temporary, sandbag wall construction was used to build the hall, and local residents without any relevant experience had to be employed during the construction of the NHC. In this contradiction, the residents are the dominant activity system. In this activity system the nodes are as follows: the subject (local labourers, VPUU architectural professionals), the object (construction of NHC - construction of sandbag walls for hall), the rules (local residents had to be employed; no permanent structure allowed by the local government), and the community (contractor who proposed mentoring programme). 
Here was a contradiction between the subject (local resident labourers) and the rules: due to the temporary nature of the building and the resultant choice of wall construction, the local resident labourers did not know how to build the wall. This had an impact on the division of labour, as the contractor overcame the contradiction by means of a mentoring process where specialist subcontractors with the required skills assisted the local resident labourers. Local labourers not able to build with sandbags is interpreted as the problem with the mentoring programme as the tool with which the problem was addressed. The germ cell is that lack of relevant construction skills can be addresses by mentoring programme while work is ongoing. As has been the case in a different case study elsewhere one of the key facets of resourcefulness was the capacity of residents to enlist all kinds of people in their initiatives, and for residents to be enlisted in diverse roles, which in turn gave rise to different skills and capacities (Simone, 2014: 324). The contractual obligation agreed upon between VPUU and the contractor (that local residents be employed), based on residents' insistence for local ownership and participation in the project, was a way of ensuring continuous participatory engagement. There was therefore no need for concern about the extent of support provided by the contractor in the participatory engagement process with the residents, as it was stipulated in the contract.

\subsection{Contradiction 3}

In the third contradiction the dominant activity includes both residents and local government. The nodes of the activity system are as follows:

- Subject: VPUU architectural professionals (residents); CoCT water and sanitation line department (local government)

- Object: Implementing a sewerage system

- Community: Volunteers who maintain the sewerage system (residents)

- Division of labour: VPUU architectural professionals remained involved after practical completion date (residents); cleaning of portable toilet by external contactor (residents); installation of sewer line (local government)

The use of a non-conventional greywater recycling system resulted in challenges which were too complex for the local committee and residents to address on their own. This is a contradiction between the rules and the community; the fact that the NHC had to be a temporary building and use a non-conventional greywater recycling system resulted in the residents who use the building could not maintain it on their own. The contradiction was overcome by the architectural professionals remaining involved in the process long after the practical completion date. Thus expanding the role of the architectural professional by it being embedded in a multi-disciplinary programme that extends beyond the construction of a building alone, but also its operation and maintenance. They arranged for portable toilets until such time as the CoCT could install a sewer line to the NHC, thereby impacting on the division of labour. A complex sewerage system to be maintained by residents emerged as a key problem, with the tools used to address the problem entailed the temporary replacement thereof with portable toilets, until a permanent sewer connection becomes available. Accordingly, the germ cell is that problems relating to temporary nature of building (having to rely on alternative technologies) can be overcome by temporary interventions until permanent solutions are implemented by local government. 


\section{Conclusion}

It is widely stated that future urban development in the global south will take place in a context of poverty and inequality (UN-Habitat, 2009; Parnell \& Oldfield, 2014). In view of this, to develop realistic notions of sustainable urbanism for low-income informal settlements in Southern Africa, it is necessary to establish a normative position. In the case study, GAP was developed as a conceptual framework to explore an emergent form of contextually appropriate architectural practice in the context of grassroots, resident-driven in situ upgrading projects. By drawing on the work of Engeström (1999b, 2009), it was determined that GAP has characteristics of pragmatic bottom-up and top-down policy-driven strategies, and occupies the conceptual space between these two types of strategies. Architectural practice in such a context requires a multi-disciplinary approach which extends beyond conventional professional boundaries and attention must be paid to building the capacity of all participants to function in such uncharted territory.

The case analysis presented in the paper offers a view into the capacities required to engage in contextually appropriate and architectural practice. We have seen operating at an interface between formal and informal requires the architectural professional to engage in activities that is beyond the scope of standard architectural practice. Attention must be paid to building the capacity of all participants to function in such uncharted territory and residents with the requisite skills to contribute to the project must be given the necessary encouragement to recognise and develop their own capacities (Jack, 2014). For example, the extended involvement of the professional (long after practical completion of the building) and having to employ non-conventional construction materials (such as sandbags). These findings have the potential to support informal settlement residents' transitions toward sustainable urbanism, and unsettle established practice by embracing the contingency which is inherent in engagements with in situ informal settlement upgrading. In doing so, this research in a small way contributes to the evolution of architectural practice in Southern Africa.

Rudolf Perold, Department of Architectural Technology and Interior Design, Cape Peninsula University of Technology, Cape Town, South Africa (peroldr@cput.ac.za)

Ronnie Donaldson, Department of Geography and Environmental Studies, Stellenbosch University, Stellenbosch, South Africa (rdonaldson@sun.ac.za)

Oswald Devisch, Faculty of Architecture and Art, Hasselt University, Diepenbeek, Belgium (oswald.devisch@uhasselt.be)

\section{Acknowledgments}

This project is supported in part by the Flemish Government (BOF Project No. R-5041) and in part by the National Research Foundation of South Africa (Unique Grant No. 99387). The assistance of VPUU staff, Lotus Park residents, and colleagues and volunteers (Kathryn Ewing, Steph Potgieter, Mark Schreuder, Andile Mayishe, Andile Jack, Philisiwe Chinyonga, Hermie Delport, Wilfried Bohm, Margaret Collins and Karin Cronjé) during the planning and execution of the live project, as well as that of Werner Boshoff for the graphic editing of figures is gratefully acknowledged. 


\section{References}

Abdel-Fattah, M. A. (2015) Grounded theory and action research as pillars for interpretive information systems research: a comparative study. Egyptian Informatics Journal, 16, pp. 309-327. DOI: $10.1016 /$ j.eij.2015.07.002

Aigbavboa, C. O. \& Thwala, W. D. (2010) Lessons learned from in situ upgrading and eradication of informal settlement in Gauteng Province in South Africa. International Journal of Housing Markets and Analysis, 3(3), pp. 233-244. DOI: 10.1108/17538271011063898

Aigbavboa, C. \& Thwala, W. (2014) Structural equation modelling of building quality constructs as a predictor of satisfaction in subsidised low-income housing. Urbani izziv, 25(Supplement), pp. 134-147. DOI: 10.5379/urbani-izziv-en-2014-25-supplement-010

Aravena, A. (2015) It's time to rethink the entire role and language of architecture. The Guardian, 20 Nov. Available at: http://www.theguardian.com/cities/2015/nov/20/rethinkrolelanguagearchitecturealejandroaravena (accessed: 23 Nov. 2015).

Bayat, A. (1997) Un-civil society: the politics of the 'informal people'. Third World Quarterly, 18(1), pp. 5372. DOI: $10.1080 / 01436599715055$

Brown-Luthango, M., Reyes, E. \& Gubevu, M. (2016) Informal settlement upgrading and safety: Experiences from Cape Town, South Africa. Journal of Housing and the Built Environment, 32(3), pp. 471-493.

Byrne, D. S. (2001) Understanding the urban. New York, Palgrave.

Chenwi, L. (2008) Upgrading of informal settlements and the rights of the poor: the case of Joe Slovo. Case review. ESR Review: Economic and Social Rights in South Africa, 9(3), pp. 13-18.

Cirolia, L., Smit, W. \& Duminy, J. (2015) Grappling with housing issues at the city scale: Mobilizing the right to the city in South Africa. In: Herrle, P., Ley, A. \& Fokdal, J. (eds.) Local action to global networks: Housing the urban poor, pp.159-174. London, Routledge.

Combrinck, C. (2015) A model to address marginality of the architectural profession in the South African discourse on informal settlement upgrade. Doctoral thesis. Pretoria, University of Pretoria.

Cooke, J. (2014) Upgrading, not eradicating, informal settlements - Listening to Steve Topham. Architecture South Africa, 66, pp. 26-27.

CRADLE (Center for Research on Activity, Development, and Learning) (2016) The activity system. Available at: http://www.helsinki.fi/cradle/activity system.htm (accessed 12 Jan. 2016).

Daniels, H. (2011) Analysing trajectories of professional learning in changing workplaces. Culture \& Psychology, 17(3), pp. 359-377. DOI: 10.1177/1354067X11408137

Datta, A. (2008) Architecture of low-income widow housing: 'Spatial opportunities' in Madipur, West Delhi. Cultural Geographies, 15, pp. 231-253. DOI: 10.1177/1474474007087500

Davis, M. (2006) Planet of slums. New York, Verso.

Dovey, K. (2013) Informalising architecture: The challenge of informal settlements. Architectural Design, 83(6), pp. 2-89. DOI: 10.1002/ad.1679

Dovey, K. \& King, R. (2011) Forms of informality: Morphology and visibility of informal settlements. Built Environment, 37(1), pp. 11-29. DOI: 10.2148/benv.37.1.11

Ekundayo, S., Wang, W. \& Andrade, A. D. (2012) The use of activity theory and its principle of contradictions to identify and analyse systemic tensions: the case of a virtual university and its partners. Paper presented at International Conference on Information Resources Management proceedings, Vienna, Austria, 21-23 May. Available at: http://aisel.aisnet.org/confirm2012/33 (accessed 31 Mar. 2016).

Engeström, Y. (1987) Learning by expanding: An activity-theoretical approach to developmental research. Helsinki, Orienta-Konsultit.

Engeström, Y. (1993) Developmental studies of work as a testbench of activity theory: the case of primary care medical practice. In: Chaiklin, S. \& Lave, J. (eds.) Understanding practice: Perspectives on activity and context, pp. 64-103. Cambridge, Cambridge University Press. DOI: 10.1017/CBO9780511625510.004

Engeström, Y. (1999a) Activity theory and individual and social transformation. In: Engeström, Y., Miettinen, R. \& Punamäki, R. L. (eds.) Perspectives on activity theory, pp. 19-38. New York, Cambridge University Press. DOI: 10.1017/CBO9780511812774.003

Engeström, Y. (1999b) Learning by expanding: Ten years after. Autobiographical note. In: Lernen durch Expansion, translated by Seeger E. Marburg, BdWi-Verlag. Available at: http://lchc.ucsd.edu/mca/Paper/Engestrom /Learning-by-Expanding.pdf (accessed 15 Mar. 2016).

Engeström, Y. (2000) Activity theory as a framework for analyzing and redesigning work. Ergonomics, 43(7), pp. 960-974. DOI: 10.1080/001401300409143

Engeström, Y. (2009) The future of activity theory: A rough draft. In: Sannino, A., Daniela, H. \& Gutierrez, K. (eds.) Learning and expanding with activity theory, pp. 303-357. Cambridge, Cambridge University Press. DOI: 10.1017/CBO9780511809989.020 
Ewing, K. (2015) Violence prevention through urban upgrading: Approach to reclaiming the public realm. Architecture South Africa, 71, pp. 28-30.

Fieuw, W. (2014) A decade after UISP: does BNG work?. Available at: http://sasdialliance.org.za/a-decadeafter-bng-does-uisp-work (accessed 12 Sep. 2014).

Gianotti, E. \& Mathiesen, A. (2014) Top down / bottom up". In: Mathiesen, A. (ed.) Scarcity in excess: The built environment and the economic crisis in Iceland, pp. 84-91. New York, Actar.

Goonewardena, K. (2008) Marxism and everyday life: On Henri Lefebvre, Guy Debord, and some others. In: Goonewardena, K., Kipfer, S., Milgrom, R. \& Schmid, C. (eds.) Space, difference, everyday life: Reading Henri Lefebvre, pp. 117-133. New York, Routledge. DOI: 10.4324/9780203933213

Gunter, A. (2014) Renting shacks: Landlords and tenants in the informal housing sector in Johannesburg South Africa. Urbani izziv, 25(supplement), pp. 96-107. DOI: 10.5379/urbani-izziv-en-2014-25-supplement007

Hiles, D. R. (2001) Heuristic inquiry and transpersonal research. Centre for Counselling and Psychotherapy Education, London, October. Available at: http://www.psy.dmu. ac.uk/drhiles/HIpaper.htm (accessed 15 Mar. 2016).

Holland, C. (2017) The evolution of street-level bureaucracy: Examining United States public education. Journal of Public Administration, 52(1), pp. 121-135.

Huchzermeyer, M. (2010) Pounding at the tip of the iceberg: The dominant politics of informal settlement eradication in South Africa. Politikon, 37, pp. 129-148. DOI: /10.1080/02589346.2010.492153

Huchzermeyer, M. (2011) Cities with 'slums': From informal settlement eradication to a right to the city in Africa. Cape Town, UCT Press.

Jack, O. (2014). Reblocking - an exercise in community planning. Architecture South Africa, 66, pp. 28-29.

Jordhus-Lier, D. (2015) Community resistance to megaprojects: The case of the N2 gateway project in Joe Slovo informal settlement, Cape Town. Habitat International, 45, pp. 169-176. DOI: 10.1016/j.habitatint.2014.02.006

Kakembo, V. \& Van Niekerk, S. (2014) The integration of GIS into demographic surveying of informal settlements: The case of Nelson Mandela Bay municipality, South Africa. Habitat International, 44, pp. 451-460. DOI: 10.1016/j.habitatint.2014.09.004

Kaptelinin, V. (2013) Activity theory. In: Lowgren, J. (ed.) The enyclopedia of human-computer interaction. Aarhus, Interaction Design Foundation.

Kleining, G. \& Witt, H. (2000) The qualitative heuristic approach: a methodology for discovery in psychology and the social sciences. Rediscovering the method of introspection as an example. Forum: Qualitative Social Research, 1(1). Available at: http:/qualitativeresearch.net/index.php/fqs/article/view/1123/2495 (accessed 15 Mar. 2016).

Lefebvre, H. [1961] (2002) Critique of everyday life: Foundations for a sociology of the everyday. vol. 2. New York, Verso.

Ley, A. (2012) Juggling with formality and informality in housing: Some lessons from the new South Africa. In: McFarlane, C. \& Waibel, M. (eds.) Urban informalities: Reflections on the formal and informal, pp. 1328. London, Ashgate.

Lipsky, M. (1969) Toward a theory of street-level bureaucracy. Paper presented at the American Political Science Association Annual Meeting, New York, 2-7 September. The American Political Science Association. Available at:

http://www.historyofsocialwork.org/1969_Lipsky/1969,\%20Lipsky,\%20toward\%20a\%20theor y\%20of\%20street\%20level\%20bureaucracy\%20OCR\%20C.pdf (accessed 2 Jan. 2016).

Mah, K. W. \& Rivers, P. L. (2013) Negotiating difference in postapartheid housing design. African Identities, 11(3), pp. 290-303. DOI: 10.1080/14725843.2013.828996

Mariotti, J. \& Kozelj, J. (2016) Tracing post-communist urban restructuring: Changing centralities in central and eastern European capitals. Urbani izziv, 27(1), pp. 113-122. DOI: 10.5379/urbani-izziv-en-2016-27-01002

Mayet, M. (1995) Responding to context and culture (complexities and contradictions). Architectural Review, pp. 48-49.

Meadowcroft, J. (2011) Engaging with the politics of sustainability transitions. Environmental Innovations and Societal Transitions, 1, pp. 70-75. DOI: 10.1016/j.eist.2011.02.003

Miles, M. (2013) Participation: Housing and urban viability. Journal of Architecture and Urbanism, 37(3), pp. 218-225. DOI: 10.3846/20297955.2013.832483

Murray, M. (2008) Taming the disorderly city: The spatial landscape of Johannesburg after apartheid. Cape Town, UCT Press.

Newton, C. (2013) The peoples housing process ... Getting the quality in the quantity?. Journal of Housing and the Built Environment, 28, pp. 639-651. DOI: 10.1007/s10901-013-9349-2 
Oldfield, S., Parnell, S. \& Mabin, A. (2004) Engagement and reconstruction in critical research: Negotiating urban practice, policy and theory in South Africa. Social \& Cultural Geography, 5(2) pp. 285-299. DOI: 10.1080/14649360410001690268

Osman, A. (2015) What architects must learn from South African student protests. The Conversation, 23. Available at: http://www.theconversation.com/whatarchitectsmustlearnfromsouthafricanstudentprotests5067 8 (accessed 25 Nov. 2015).

Pieterse, E. (2004) Sketches of development praxis against a horizon of complexity. In: Pieterse, E \& Meintjies, $\mathrm{F}$ (eds.) Voices of the transition: The politics, poetics and practices of social change in South Africa, pp. 329-352. Sandown, Heinemann.

Roy, A. (2005) Urban informality. Toward an epistemology of planning. Journal of the American Planning Association, 71(2), pp. 147-158. DOI: 10.1080/01944360508976689

Royston, L. (2009) A significantly increased role in the housing process: The municipal housing planning implications of BNG. Stads-en Streeksbeplanning - Town and Regional Planning, 54, pp. 63 -73.

Schoon, S. \& Altrock, U. (2014) Conceded informality: Scopes of informal urban restructuring in the Pearl River Delta. Habitat International, 43, pp. 214-220. DOI: 10.1016/j.habitatint.2014.03.007

Seamon, D. (2000) A way of seeing people and place: Phenomenology in environment-behavior research. In: Wapner, S., Demick, J., Yamamoto, T. \& Minami, H. (eds.) Theoretical perspectives in environmentbehavior research: Underlying assumptions, research problems, and methodologies, pp. 157-178. New York, Plenum. DOI: 10.1007/978-1-4615-4701-3_13

Simone, A. (2014) The missing people: Reflections on an urban majority in cities of the South. In: Parnell, S. \& Oldfield, S. (eds.) The Routledge handbook on cities of the Global South, pp. 322-326. London, Routledge.

Sverrisdóttir, H. (2014) The sociopolitical role of the architect. In: Mathiesen, A. (ed.) Scarcity in excess: The built environment and the economic crisis in Iceland, pp. 104-107. New York, Actar.

Tissington, K. (2010) A review of housing policy and development in South Africa since 1994. Paper prepared for the Studies in Poverty and Inequality Institute (SPII). Socio Economic Rights Institute. Typescript.

Tummers, L. \& Bekkers, V. (2014) Policy implementation, Street-level bureaucracy, and the importance of discretion. Public Management Review, 16(4), pp. 527-547. DOI: 10.1080/14719037.2013.841978

UN-Habitat. (2009) Global Report on Human Settlements 2009: Planning for Sustainable Cities. London, Earthscan.

Varley, A. (2013) Postcolonialising informality?. Environment and Planning D: Society and Space, 31, pp. 422. DOI: $10.1068 / \mathrm{d} 14410$

VPUU (Violence Prevention through Urban Upgrading) (2011) Lotus Park Informal Settlement upgrade baselines. Internal report, August. Cape Town.

VPUU (2014a) Violence Prevention through Urban Upgrading (VPUU): Summary of achievements. Internal report, July. Cape Town.

VPUU (2014b) Lotus Park Informal Settlement: Spatial reconfiguration plan. Internal report, July. Cape Town.

Yaneva, A. (2011) From reflecting-in-action towards mapping of the real. In: Doucet, I. \& Janssens, N. (eds.) Transdisciplinary knowledge production in architecture and urbanism: Towards hybrid modes of inquiry, pp. 117-128. London, Springer. DOI: /10.1007/978-94-007-0104-5_8

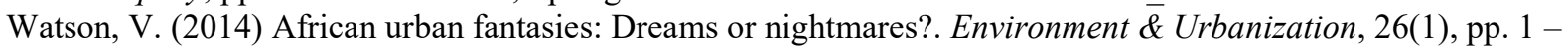 17. DOI: $10.1177 / 0956247813513705$

Ziblim, A. (2013) The dynamics of informal settlement upgrading in South Africa: Legislative and policy context, problems, tensions, and contradictions. Report. Bratislava, Habitat for Humanity International. Available at: http://globalhousingindicators.org/sites/globalhousingindicators.org/files/The\%20 Dynamics\%20of\%20Informal\%20Settlements\%20Upgrading\%20in\%20South\%20Africa.pdf (accessed 23 Feb. 2015). 